\title{
Borsa İstanbul'da İşlem Gören Sigorta Şirketlerinin Karşılaştırmalı Finansal Performans Analizi
}

\author{
Comparative Analysis of Financial Performance of Insurance \\ Companies Listed in Borsa Istanbul
}

\author{
Yrd. Doç. Dr. Mehmet Fatih Bayramoğlu - Öğr. Grv. Dr. Çağatay Başarır
}

\section{Öz}

Gelişen bir finans piyasasına sahip olan Türkiye'de, sigorta sektörünün de bu gelişmeye uyum sağladiğı görülmektedir. Özellikle bireysel emeklilik sisteminin getirilmesi ve devlet destekli bir yaprya kavuşturulmasl ayrica sigorta sektörü ile ilgili yasalara yönelik iyileştirmeler, bu sektörün gelişimine önemli katkılarda bulunmaktadır. Bu çalışmada, Borsa İstanbul'da işlem gören altı adet sigorta şirketinin oran analizi yaklaşımi ile birbirleriyle karşılaştırmal finansal performans analizi yapılmıştır. Çalışma kapsamında 2011-2014 yıllarına ilişkin yıllık mali tablolar kullanılmış olup, bu tablolardan elde edilen mali oranlarn TOPSIS yöntemi ile finansal performans analizi gerçekleştirilmiştir. Çalışma sonuçlarına göre ilgili dönemde, dört firmanın farkl seviyelerde olmakla birlikte finansal açıdan başarılı olduğu, iki firmanin ise başarısız olduğu belirlenmiştir.

Anahtar Kelimeler: Sigorta Sektörü, Performans Analizi, TOPSIS.

\section{Abstract}

In Turkey, which has a developing financial market it can be observed that the insurance industry is also developing. Improvements in legislation regarding the insurance industry, especially establishment of supplementary retirement insurance which is supported by the state has contributed greatly to the development of this industry. This study analyzes the comparative financial performance of six insurance companies shares being traded in Borsa Istanbul through ratio analysis. The study employs financial statements covering the period 2011-2014 and analyzes the financial performance as calculated from these tables through TOPSIS method. Findings show that while four firms are successful, albeit at different levels, two are unsuccessful.

Keywords: Insurance Industry, Performance Analysis, TOPSIS.

\section{Giriş}

Sigorta, varlığı bilinmeyen, ileride meydana gelme ihtimali bulunan tehlikelere karşı bireyleri ve varlıkları, yaşanacak tehlikeden doğan zararların giderilmesi için önceden yapılan ödemeler ile güvence altına alma işlemidir. Bunun dişında sigorta sektörü, ülke ekonomisine uzun vadeli kaynak finansı sağlayarak ekonomiyi güçlendirme, fon yaratma, devlete vergi geliri sağlama gibi fonksiyonları yerine getirerek ekonominin büyümesinde ve gelişmesinde oldukça etkili ve önemli bir rol üstlenmektedir (Taş, 2015, s. 134).Dolayısıyla gelişmiş ve gelişmekte olan ülkelerde finansal piyasaların en önemli unsurlarından biri sigorta sektörüdür.

Yrd. Doç. Dr. Mehmet Fatih Bayramoğlu, Bülent Ecevit Üniv. İ̈BF / Lamar University, USA (Misafir Öğretim Üyesi), fatih.bayramoglu@beun.edu.tr Çağatay Başarır, Bandırma Onyedi Eylül Üniversitesi Bandırma MYO, cbasarir@balikesir.edu.tr 
Sigorta sektörünün hem makro boyutta hem de mikro boyutta olmak üzere yararları söz konusudur. Makro açıdan bakıldığında öncellikle ekonomik gelişmenin temel unsuru olan tasarrufları arttırdığ 1 için ekonomik büyümeyi etkilediği söylenebilmektedir. Bununla birlikte, sosyo-ekonomik yıkımların önlenmesine, sosyal güvenlik sisteminin yükünün hafifletilmesine ve vergi kaynağı oluşturması nedeniyle büyük bir oranda istihdama da katkı sağlamaktadır. Mikro boyutta ise küçük esnafın kararlarını olumlu yönde etkilemekte ve girişimcilerin daha uygun maliyetle yatırım sermayesi bulmalarını sağlamaktadır. Aynı zamanda sigorta sayesinde daha kolay ve uygun koşullarda kredi bulmalarını olanaklı kılmaktadır (Kahya, 2000, s. 24).

Sigorta sektörü, gelişmiş ülkelerde en önemli sektörlerden birisi olup gelişmekte olan ülkelerde ise en dinamik ve gelişmeye en açık sektördür. Sigorta sektörünün gelişmekte olan ülkelerde daha hızlı bir şekilde geliştirilebilmesinin temelinde tasarruf eğiliminin arttırılarak bunun finansal piyasalara aktarılmasının sağlanması yer almaktadır.

Finansal piyasalar, ülke ekonomilerinin gelişmeleri için gerekli olan fon paylaşım ortamını oluşturması açısından önemli bir işlevi yerine getirmektedir. Sigorta sektörü ise başta bankacılık sektörü olmak üzere para ve sermaye piyasalarının önemli bir unsurunu oluşturmaktadır. Bu nedenle para ve sermaye piyasalarıyla yoğun bir ilişki içerisinde olan sigorta sektörüne ve bu sektörde yer alan şirketlerin yapısal durumuna ilişkin analizlere daha ihtiyaç duyulmaktadır. Bu çalışma ile Borsa İstanbul A.Ş.de işlem gören altı adet şirketin finansal durumuna yönelik performans değerlemesi yapılmasını ve bu firmaların elde edilen bulgular çerçevesinde birbirleriyle karşılaştırmalı olarak bir sıralamaya tabi tutulmasını amaçlamaktadır. Bu çerçevede, sigorta şirketlerinin 2011-2014 dönemine ilişkin mali oranları, TOPSIS yöntemi ile analiz edilerek dört yıllık finansal performans değerlendirmesi yapılmıştır. Elde edilen bulgular çerçevesinde sigorta şirketlerinin sektöre ve yatırımcılara yönelik değerlendirmelerine yer verilmiştir.

Bu çalışanın izleyen bölümlerinde; öncelikle Türkiye Sigorta Sektörünün genel görünümüne, ardından s1rasıyla literatür incelemesi, yöntem ve uygulamaya yer verilmiştir. Son olarak bulgular çerçevesinde değerlendirmeler yapılmış ve sonuç kısmı oluşturulmuştur.

\section{Türkiye Sigorta Sektörünün Genel Görünümü}

Sigorta sadece riskleri teminat altına alan ve riskler gerçekleştiği zaman ortaya çıkan hasarların ödenmesini sağlayan bir sistem değildir. Bununla birlikte prim gelirlerinden oluşan fon gücünü yatırım alanlarına aktarmak suretiyle ekonomik gelişmeye de önemli ölçüde finansal kaynak sağlayan bir sistemdir (Genç, 2002, s. 5).

Bir sigorta şirketi, sigortasını yaptığı işlerin risklerinden bir kısmını üzerine alırken, bir kısmını da reasürans şirketlerine devretmektedir. Reasürans şirketleri de bu risklerin bir kısmını üzerinde tutmakta diğer kısmını ise yine başka şirketlere devretmektedir. Dolayısıyla farklı ülkelerde meydana gelen riskler, birbirini etkileyebilmektedir (Başpınar, 2005, s. 5).

Sigorta şirketleri, finansal sistemin işlevlerini yerine getirmesini sağlayan finansal aracılar arasında önemli bir role sahiptir. Hem şirketler hem de bireyler için bu şirketler temel risk yönetimi kurumlarıdır. Sigorta şirketleri, sigorta poliçeleri ihraç ederek fon toplarlar ve topladıkları bu fonları reel yatırımların finanse edilmesi amaciyla sektörlere transfer ederler. Bu nedenle teoride, sigorta şirketleri ekonomik büyümeyi destekleyen bir unsur olarak ele alınabilmektedir. Gelişmekte olan ülkelerde sigorta sektörünün önemi giderek artmaktadır. Gelişmekte olan Avrupa Birliği ülkelerinde hayat sigortalarının yaygınlığı 1992 ile 2007 yılları arasında ortalama GSYİH'nın yüzde 0,4'ünden yüzde 1,5'ine yükselmiştir. Aynı dönemde hayat sigortası dışındaki sigortaların yaygınlığı ortalama GSYİH'nın yüzde 1,5'inden yüzde 2'sine yükselmiştir (Curak vd., 2009, s. 30-31).

Sigorta şirketlerinin finansal performansı normalde, kazanılmış net prim, sigortalama işlemlerinden elde edilen karlar, yıllık devir, yatırım karlılığı, özkaynak karlılığı, özkaynak verimliliği gibi ölçütlerle tanımlanmaktadır. Bu ölçütler kar performans ölçütleri ve yatırım performans ölçütleri olarak sınıflandırılabilmektedir. Bütçe sapması her iki birimin de finansal performansını ölçmektedir. Her iki dalın da performansı hem finansal hem de finansal olmayan performans1 içermektedir. Finansal performans, kar performansı ve yatırım performansı olarak ikiye ayrılabilir. Bu ölçütleri tanımlamada ise ciro hadleri, brüt ve net kar, yatırım karlılığı, kullanılan sermayenin getirisi gibi terimler kullanılabilmektedir (Kasturi, 2006, s. 7-8). 
Sigorta şirketlerinin finansal performansı, poliçe sahipleri, çalışanlar, hissedarlar, aracı kurumlar, potansiyel yatırımclar, denetim otoriteleri ve diğer tüm paydaşlar açısından büyük önem taşımaktadır. $\mathrm{Bu}$ nedenle sigorta şirketlerinin finansal performansının ölçülmesi ve performansa etki eden faktörlerin belirlenmesi son yıllarda araştırmacıların dikkatini çeken bir konu haline gelmiştir (Kaya ve Kaya, 2015, s. 95).

Türkiye’de sigorta sektöründe, 2007 yılında çıkartılan 5684 sayll Sigortacilık Kanunu ile yeni bir dönem başlamıştır. Bu kanun ile birlikte sigorta sektörü $\mathrm{AB}$ düzenlemeleri ile uyumlu bir mevzuata kavuşmuş ve daha sağlam bir yapıya bürünmüştür.

Türkiye sigorta sektörünün finansal sektör içerisindeki payı her geçen gün artış sergilemiştir. 2013 yı- lında \%3,33 olan payı, 2014 yılında \% 3,64 oranına yükselmiştir. Sigorta sektörüne ilişkin temel veriler Tablo 1'de gösterilmektedir. Sigorta sektörünün aktif büyüklüğü 2013 yılında 64,3 milyar TL iken 2014 yılında 81 milyar TL seviyesine çıkarak yaklaşık \%26'llk bir artışa ulaşmıştır. Sektörde faaliyette bulunan şirket sayısı 2013 yılında 61 iken bu rakam 2014 yılında 63’e çıkmıştır.

Yll içinde toplam 26 milyar TL prim üretimi gerçekleştiren sektör, bir önceki yıla göre nominal \%6,9 oranında artış göstermiştir. Toplam prim üretimindeki artış oranının ise 1998 yılı sabit fiyatlarıyla karşılaştırıldığında \%1,5 oranında düştüğü gözlemlenmektedir.

Sigorta sektörü büyümeye devam ederken mali sağlamlığını da korumaktadır. Mali sağlamlılık açısın-

Tablo 1. Türk Sigorta Sektörüne Iliş̧kin Temel Veriler

\begin{tabular}{|l|r|r|r|r|r|}
\hline & $\mathbf{2 0 1 0}$ & \multicolumn{1}{|c|}{$\mathbf{2 0 1 1}$} & $\mathbf{2 0 1 2}$ & $\mathbf{2 0 1 3}$ & $\mathbf{2 0 1 4}$ \\
\hline Toplam Şirket Sayısı(Adet) & 58 & 59 & 59 & 61 & 63 \\
\hline İstihdam(Kişi) & 16.029 & 16.783 & 17.521 & 18.511 & 19.305 \\
\hline Toplam Prim Üretimi(Milyar) & 14,1 & 17,2 & 19,8 & 24,2 & 26 \\
\hline Aktif Büyüklük(Milyar) & 36,8 & 42,5 & 52,6 & 64,3 & 81 \\
\hline D.Prim Üretimi/GSYH(\%) & 1,26 & 1,29 & 1,37 & 1,51 & 1,45 \\
\hline
\end{tabular}

Kaynak: Hazine Müsteşarlığı 2014 Yılı Sigortacılık ve Bireysel Emeklilik Faaliyet Raporu

dan kullanılan oran olan sermaye yeterlilik rasyosu 2014 yılında hayat dışı şirketlerde \%136, hayat / emeklilik şirketlerinde ise \%387 olarak gerçekleşmiştir. Bu veriler, sektörün, yükümlülüklerini karşllayabilecek özkaynağa fazlasıyla sahip olduğunu göstermektedir(Hazine Müsteşarlığı, Sigortacilık ve Bireysel Emeklilik Faaliyet Raporu, 2014, s.1-4).

\section{Literatür}

Literatürde, Borsa İstanbul'un alt sektörlerinde işlem gören şirketlerin ve bankacilık sektörünün görece finansal performanslarının değerlendirmesinde TOPSIS yöntemine sıkça başvurulduğu görülmektedir. Ancak TOPSIS yönteminin Türkiye sigorta sektörü özelinde kullanımına ilişkin bir çalışmaya yapılan literatür incelemesi çerçevesinde ulaşılamamıştır.
İç vd. (2015), 24 adet sektörde faaliyet gösteren 198 adet firmanın finansal performansının ölçümünde TOPSIS, VIKOR, GRA, MOORA yöntemlerini kullanmışlardır. Sonuçlar, en başarılı performans değerlendirmesinin TOPSIS yöntemi ile yapıldığını ortaya koymuştur. Ergül (2014), BIST Turizm Sektöründe faaliyet gösteren 7 adet şirketin 2005-2012 yılları arası finansal performanslarının ölçümünde TOPSIS ve ELECTRE yöntemlerini kullanmıştır. Ege vd. (2013), BIST Kurumsal Yönetim Endeksi'nde yer alan 18 adet şirketin 2009-2012 yılları arası performans karşılaștırmasını yapmıs ve finansal performans ile kurumsal yönetime uyumluluk arasındaki ilişkiyi araştırmıştır. Ömürbek ve Kınay (2013), BIST’te işlem gören bir havayolu taşımacısı işletme ile Frankfurt Borsası'nda işlem gören bir havayolu taşımacısı işletmenin 2012 yılına ilişkin finansal performansının karşılaştırılma- 
sını yapmıştır. Aytekin ve Sakarya (2013), BIST'te işlem gören 20 adet gida işletmesinin 2009-2012 yılları arası finansal performansını ölçmüştür. Yılmaz Türkmen ve Çağıl (2012), BIST Bilişim Sektöründe faaliyet gösteren 12 adet firmanın 2007-2010 yılları arası finansal performansını ölçmüştür. Akyüz vd. (2011), BIST'de işlem gören bir seramik şirketinin 1999-2008 yılları arası finansal performansını değerlendirmiştir. Yayar ve Baykara (2012), Türkiyede faaliyet gösteren 4 adet katılım bankasının 2005-2011 yılları arası etkinliğini ve verimliliğini değerlendirmişlerdir. Çonkar vd. (2011), Borsa İstanbul Kurumsal Yönetim Endeksi'nde 2007 yllında yer alan 7 adet şirketin ve 2008 yilında yer alan 10 adet şirketin finansal performansının ölçümünü yapmıştır. Dumanoğlu ve Ergül (2010), BIST Teknoloji Sektöründe faaliyet gösteren 11 adet şirketin 2006-2009 yılları arası finansal performansını ölçmüştür. Demireli (2010), 2001-2007 yılları arasında Türkiye'de faaliyet gösteren 3 adet kamu bankasının performansını değerlendirmiştir.

Uluslararası çalışmalara bakıldığında ise finansal performans değerlendirilmesi açısından TOPSIS yönteminin kullanıldığı birçok çalışmaya rastlanılmakla birlikte bu çalışmaların genelde diğer sektörlere ilişkin olduğu görülmektedir. Bundan dolayı uluslararası çalışmalarda sadece sigorta sektörünün finansal performansını ölçmeye yönelik olarak yapılmış belli başlı kaynaklar incelenebilmiştir. Akotey vd. (2013), yapmış oldukları çalışmada 2000-2010 yılları arasında Gana'da faaliyette bulunan 10 adet hayat sigortası şirketinin finansal performansı ile karlılık oranları arasındaki ilişkiyi panel veri analizi yöntemiyle incelemişlerdir. Benzer bir şekilde Almajali vd. (2012), y1linda Umman Borsasında faaliyette bulunan 25 adet sigorta şirketinin performansını 2002-2007 yılları için araştırmışlardır. Çalışmada bağımsız değişken olarak kaldıraç oranı, likidite oranı, yönetim etkinlik endeksi, firma büyülügü ve yaşı kullanılmış, bağımlı değişken olarak ise firmaların finansal performansları ele alınmıştır. Bawa ve Chattha (2013), Hindistan'da faaliyette bulunan 18 adet sigorta firmasının aylık verilerini kullanarak 2002-08 ve 2011-12 dönemi için finansal performansları ölçmek amacıyla çoklu lineer regresyon analizi yapmışlardır. Çalışmada finansal performans ölçütü olarak karlılık oranlarını kullanmışlar ve bağımsız değişken olarak ise likidite, ödeme gücü, kaldıraç, büyüklük ve özsermaye oranlarını kullanmışlardır. Bağımsız değişkenlerden hangisi ya da hangilerinin karlılık üzerinde etkisinin olduğunu tespit etmeye çalışmışlardır.
TOPSIS yöntemin kullanıldığı ilgili ampirik literatürün genel bir değerlendirmesi bu yöntemin finansal performans değerlendirmesi uygulamalarında başarılı sonuçlar verebildiğini anlaşılmaktadır.

\section{Yöntem}

$\mathrm{Bu}$ çalışmada, sigorta şirketlerinin finansal performanslarının karşılaştırılmasında TOPSIS (technique for order preference by similarity to an ideal solution) yöntemi kullanılmıştır. Çok kriterli karar verme tekniklerinden TOPSIS yöntemi, Hwang ve Yoon tarafından geliştirilmiştir. Yöntemin temeli, ideal çözüme en yakın mesafede olan ve negatif ideal çözüme en uzak mesafede olan alternatifin seçilmesine dayanmaktadır (Hwang and Yoon, 1981, s. 128). TOPSIS yöntemi, aşağıdaki adımların takip edilmesiyle hesaplanır (Jahanshahloo vd., 2006, s. 1547-1548):

Adım-1: Yöntemin ilk aşamasında satırlarında performansı karşılaştııılmak istenen birimlerin yer aldı$\breve{g} 1$, sütunlarında ise karar vermede kullanılacak nitelik ya da kriterlerin yer aldığı karar matrisi oluşturulur. Karar matrisi Eşitlik 3.1'de görüldüğü gibidir:

$X_{i j}=\left[\begin{array}{lll}x_{11} & x_{21} & x_{1 j} \\ x_{12} & x_{22} & x_{2 j} \\ x_{i 1} & x_{i 2} & x_{i j}\end{array}\right]$

Adım-2: Normalize Karar Matrisi hesaplanır. Böylece yüksek değerlere sahip veri seti -1 ile 1 aralığına indirgenmiş olur. Normalize edilmiş değerler $n_{i j}$, Eşitlik 3.2'de gösterildiği gibi hesaplanır:

$n_{i j}=\frac{x_{i j}}{\sqrt{\sum_{i=1}^{m} x_{i j}^{2}}}, i=1, \ldots, m, j=1, \ldots, n$.

Adım-3: Ağırlıklı Normalize Karar Matrisi hesaplanır. Ağırlık normalize değerler $v_{i j}$, Eşitlik 3.3’te gösterildiği gibi hesaplanır:

$v_{i j}=w_{j} n_{i j}, i=1, \ldots, m, j=1, \ldots, n$.

burada, $w_{j}, \sum_{i=1}^{n} w_{j}=1$ olmak üzere, i. nitelik veya kriterin ağırlığını göstermektedir.

Adım-4: İdeal çözümler ve negatif ideal çözümler hesaplanır. İdeal çözümlerin hesaplanması Eşitlik 3.4'te, Negatif ideal çözümlerin hesaplanması ise Eşitlik 3.5’te gösterildiği gibi hesaplanır: 


$$
\begin{aligned}
& A^{+}=\left\{v_{1}^{+}, \ldots, v_{n}^{+}\right\}=\left\{\left(\max _{j} v_{i j} \mid i \in I\right),\left(\min _{j} v_{i j} \mid i \in J\right)\right\}, \\
& A^{-}=\left\{v_{1}^{-}, \ldots, v_{n}^{-}\right\}=\left\{\left(\min _{j} v_{i j} \mid i \in J\right),\left(\max _{j} v_{i j} \mid i \in I\right)\right\},
\end{aligned}
$$

burada, $I$ "fayda" nitelik veya kriterini, $J$ ise "maliyet" nitelik veya kriterini ifade etmektedir. Bu aşamada yöntemin uygulayıcısının, Adım-6'da hesaplanacak olan "ideal çözüme görece yakınlık değerlerini $\left(R_{i}\right)$ " doğru hesaplayabilmesi için, her bir karar kriterinin "fayda" veya "maliyet" niteliğinden (kriterinden) hangisi açısından önemli olduğunu belirlemiş olması gerekmektedir.

Adım-5: Pozitif ideal ve Negatif ideal ayırım ölçüleri hesaplanır. TOPSIS yönteminde her bir karar noktasına ilişkin değerlendirme faktör değerinin ideal ve negatif ideal çözüm setlerinden sapmalarının bulunabilmesi için Euclidian Uzaklık Yaklaşımı’ndan yararlanılmaktadır. Buradan elde edilen karar noktalarına ilişkin sapma değerleri ise Pozitif ideal ayırım ölçüleri $d_{i}^{+}$ve Negatif ideal ayırım ölçüleri $d_{i}^{-}$olarak adlandırılır. Pozitif ideal ayırım ölçülerinin hesaplanması Eşitlik 3.6'da, Negatif ideal ayrım ölçülerinin hesaplanması ise Eşitlik 3.7'de gösterildiği gibi hesaplanır:

$$
\begin{aligned}
& d_{i}^{+}=\left\{\sum_{j=1}^{n}\left(v_{i j}-v_{j}^{+}\right)^{2}\right\}^{1}, \quad i=1, \ldots, m, \\
& d_{i}^{-}=\left\{\sum_{j=1}^{n}\left(v_{i j}-v_{j}^{-}\right)^{2}\right\}^{\frac{1}{2}}, \quad i=1, \ldots, m,
\end{aligned}
$$

Adım-6: İdeal çözüme görece yakınlık değerleri $\left(R_{i}\right)$ hesaplanır. Bu hesaplamanın yapılması için Negatif ideal ayırım ölçülerinin $d_{i},\left(d_{i}^{+}+d_{i}^{+}\right)$toplam ayırım ölçüsü içerisindeki payı hesaplanır. İdeal çözüme görece yakınlık değerleri $R_{i}$, Eşitlik 3.8'de gösterildiği gibi hesaplanır.

$R_{i}=d_{i}^{-} /\left(d_{i}^{-}+d_{i}^{+}\right), \quad i=1, \ldots, m$.

burada, $d_{i}^{-} \geq 0$ ve $d_{i}^{+} \geq 0$, ve $R_{i} \in[0,1]$ 'dir.

Adım-7: İdeal çözüme görece yakınlık değerleri $R_{i}$, büyükten küçüğe doğru sıralanır. En yüksek $R_{i}$ değerine sahip olan, TOPSIS yöntemine göre diğerlerine göre performansı en yüksek olanı, diğer bir ifadeyle İdeal çözüme görece yakınlık değeri en yüksek olanı verir.

\section{Uygulama}

Bu çalışma kapsamında 2011-2014 döneminde Borsa İstanbul A.Ş.de işlem gören altı adet sigorta şirketine ilişkin dört y1llık finansal performans değerlemesinin, birbirleriyle kıyaslanarak yapılması amaçlanmıștır. Bu şirketler; "Ak Sigorta-AKGRT", "Anadolu Sigorta-ANSGR", "Güneș Sigorta-GUSGR", "Halk Sigorta-HALKS", "Ray Sigorta-RAYSG” ve "Aviva Sigorta-AVIVA"dır.

Finansal performans değerlemesi için firmaların yıllık olarak açıklamış oldukları mali tablolardan yararlanılmıştır. Bu mali tablolardan sigorta şirketlerinin finansal performans ölçümünde kullanılabilecek ve ilgili literatür çerçevesinde belirlenmiş olan 10 adet mali oran hesaplanmıştır. Mali tablolar, Kamuyu Aydinlatma Platformu (KAP) web sitesinden ücretsiz olarak temin edilmiştir. Hesaplanan oranlar (karar kriterleri) ve bu oranların TOPSIS yönteminin 6 . adımında hesaplanacak olan "ideal çözüme görece yakınlık değerlerinin $\left(R_{i}\right)$ " hesaplanmasında "fayda" veya "maliyet" niteliğinden hangisi açısından önemli olduğuna ait bilgi Tablo 2'de verilmiştir.

Hesaplanan oranlar yardımıyla firmaların birbirlerine göre finansal performanslarını değerlendirmek amacıyla TOPSIS yönteminden yararlanılmıştır. TOPSIS yöntemi uygulanırken bu çalışmanın 3. Bölümünde açıklanmış olan işlem adımları takip edilmiştir.

Bu amaçla, öncelikle Tablo 2'de belirtilmiş olan finansal oranlardan, her firmayı içerecek şeklide bir karar matrisi oluşturulmuştur. Ardından Eşitlik 3.2 yardımılla bu matrisin -1 ile +1 aralığında normalize edilmesi sağlanmıştır. Bu işlemin ardından her bir finansal orana \%10 eşit ağırlık değeri verilmiş ve elde edilen ağırlık matrisi Eşitlik 3.3'ün hesaplamasında kullanılarak ağırlıklı normalize karar matrisi hesaplanmıştır. Ardından ağırlıklı normalize karar matrisi üzerinde her bir karar kriterine ilişkin en büyük ve en küçük değerler tespit edilmiştir. Burada en büyük değerler ideal çözümleri $A^{+}$ve en küçük değerler ise negatif ideal çözümleri $A^{-}$ifade etmektedir. Burada 
Tablo 2. Karar Kriterleri ve Nitelikleri

\begin{tabular}{|c|l|l|}
\hline & Mali Oran (Karar Kriteri) & Amaç (Nitelik) \\
\hline 1 & Toplam Prim Üretimi & Fayda (Maks) \\
\hline 2 & Toplam Aktifler & Fayda (Maks) \\
\hline 3 & Ödenen Hasarlar & Maliyet (Min) \\
\hline 4 & Alınan Primler/Özkaynaklar & Maliyet (Min) \\
\hline 5 & Özkaynaklar/Toplam Aktifler & Fayda (Maks) \\
\hline 6 & Özkaynaklar/Teknik Karşılıklar & Fayda (Maks) \\
\hline 7 & Konservasyon Oranı & Fayda (Maks) \\
\hline 8 & Hasar Prim Oranı & Maliyet (Min) \\
\hline 9 & Vergi Öncesi Kar-Zarar/Alınan Primler & Fayda (Maks) \\
\hline 10 & Net Kar/Özkaynaklar & Fayda (Maks) \\
\hline
\end{tabular}

açıklanması gereken önemli bir konu bu çalışmada kullanılan mali oranlar ile ilgilidir. Tablo 2'nin ikinci sütununda bu mali oranlar ile ulaşılması istenen amaçlar yer almaktadır. Örneğin; Toplam Prim Üretimi değişkeninin yüksek olması karar vericiler için olumlu iken, Ödenen Hasarlar değişkeninin düşük olması karar vericiler için olumludur. $\mathrm{Bu}$ nedenle burada ideal çözümler matrisi oluşturulurken değişkenlerin karar vericiler için "fayda" açısından mı yoksa "maliyet" açısından mı önemli olduğu göz önüne alınmıştır. Burada yapılan açıklama Eşitlik 3.4 ve Eşitlik 3.5 incelendiğinde de görülebilmektedir. $\mathrm{Bu}$ işlemlerin ardından Pozitif ideal ayrım ölçütleri $d_{i}^{+}$ve Negatif ideal ayırım ölçüleri $d_{i}$, Eşitlik 3.6 ve Eşitlik 3.7 yardımıyla hesaplanmıştır. Son olarak Eşitlik 3.8 kullanılarak her sigorta şirketinin İdeal çözüme görece yakınlık değeri $R_{i}$ hesaplanmıştır. Elde edilen $R_{i}$ değerlerine göre sigorta şirketlerinin görece finansal performans sıralaması yapılmıştır. Bu çalışmada gö- rece finansal performans değeri 2011-2014 yılları için yapıldığından, bu paragrafta açıklanan işlemler dört defa tekrarlanmıştır. Böylece Tablo 3 elde edilmiştir.

\section{Bulgular ve Değerlendirme}

Çalışmanın bu kısmında TOPSIS yöntemi kullanılarak altı adet sigorta şirketinin birbirleriyle karşılaştırmalı olarak hesaplanan finansal performans sonuçlarına yer verilmiştir. Tablo 3'te sigorta şirketlerinin İdeal Çözüme Yakınlık Değerleri $\left(R_{i}\right)$ görülmektedir. Tablo 3’ten görüleceği üzere, 2011-2013 yılları arasında en yüksek değeri "Aksigorta" şirketine aittir. 2014 yılında ise en yüksek $R_{i}$ değerine sahip sigorta şirketi "Anadolu Sigorta” olmuştur. 2011, 2012 ve 2014 yllarında en düşük $R_{i}$ değerine "Aviva Sigorta" sahipken, 2013 yllında ise en düşük $R_{i}$ değerine "Güneş Sigorta" sahiptir.

Tablo 3. Sigorta Şirketlerinin İeal Çözüme Yakınlık Değerleri (2011-2014)

\begin{tabular}{|c|l|c|l|c|l|l|l|c|}
\hline Sıra No & $\begin{array}{c}\text { Sigorta } \\
\text { Şirketi }\end{array}$ & $\begin{array}{c}\mathbf{R i} \\
\mathbf{2 0 1 1}\end{array}$ & $\begin{array}{c}\text { Sigorta } \\
\text { Şirketi }\end{array}$ & $\begin{array}{c}\mathbf{R i} \\
\mathbf{2 0 1 2}\end{array}$ & $\begin{array}{c}\text { Sigorta } \\
\text { Şirketi }\end{array}$ & $\begin{array}{c}\text { Ri } \\
\mathbf{2 0 1 3}\end{array}$ & $\begin{array}{c}\text { Sigorta } \\
\text { Şirketi }\end{array}$ & $\begin{array}{c}\mathbf{R i} \\
\mathbf{2 0 1 4}\end{array}$ \\
\hline 1 & AKGRT & 0.633 & AKGRT & 0.653 & AKGRT & 0.622 & ANSGR & 0.731 \\
\hline 2 & GUSGR & 0.615 & GUSGR & 0.608 & HALKS & 0.553 & AKGRT & 0.722 \\
\hline 3 & ANSGR & 0.609 & HALKS & 0.581 & ANSGR & 0.497 & GUSGR & 0.716 \\
\hline 5 & RAYSG & 0.527 & RAYSG & 0.550 & RAYSG & 0.400 & HALKS & 0.676 \\
\hline 6 & HALKS & 0.402 & ANSGR & 0.550 & AVIVA & 0.373 & RAYSG & 0.637 \\
\hline
\end{tabular}


Firmaların birbirlerine görece olarak göstermiş oldukları finansal performansı daha açık olarak görmek üzere Tablo 4 ve Tablo 5 hazırlanmıştır. Tablo 4'te, altı adet sigorta şirketinin $R_{i}$ değerine göre sıra- laması gösterilmektedir. Bu sıralamadan da görüleceği üzere 2011-2014 yılları arasında en yüksek görece finansal performansı "Ak Sigorta", en düşük görece finansal performansı ise "Aviva Sigorta" göstermiștir.

Tablo 4. Sigorta Şirketlerinin İdeal Çözüme Yakınlık Değerleri Sıralaması (2011-2014)

\begin{tabular}{|c|c|c|c|c|}
\hline Sigorta Şirketi & $\mathbf{2 0 1 1}$ & $\mathbf{2 0 1 2}$ & $\mathbf{2 0 1 3}$ & $\mathbf{2 0 1 4}$ \\
\hline AKGRT & 1 & 1 & 1 & 2 \\
\hline GUSGR & 2 & 2 & 6 & 3 \\
\hline ANSGR & 3 & 5 & 3 & 1 \\
\hline RAYSG & 4 & 4 & 4 & 5 \\
\hline HALKS & 5 & 3 & 2 & 4 \\
\hline AVIVA & 6 & 6 & 5 & 6 \\
\hline
\end{tabular}

Tablo 5'te ise sigorta şirketlerinin görece finansal performanslarını değer olarak vermek amacıyla hesaplanan ortalama finansal performans endeksinin "sira puanına göre" ve "yüzde puanına göre" değerleri yer almaktadir.

Sıra puanına göre endeks değeri, sigorta şirketlerinin $R_{i}$ değerine göre siralanmasında yıllık bazda 1 . sıradaki şirkete 6 puan, 6 . sıradaki şirkete ise 1 puan vermek suretiyle puanlandırılmasıyla oluşturulmuştur. Böylece sigorta şirketleri, $R_{i}$ değerine göre yer aldıkları s1- rada en yüksek değere sahip olana en yüksek puanın verilmesi suretiyle 1-6 arasında puanlandırılmıştır. Ardından dört yıl için ayrı ayrı hesaplanmış bu puanların ortalamaları alınarak "Sıra Puanına Göre Ortalama Finansal Performans Değeri”ne ulaşılmıştır.

Yüzde puanına göre endeks değeri ise, sigorta şirketlerinin "Sıra Puanına Göre Ortalama Finansal Performans Değeri”nin, “En Yüksek Teorik Sıra Puanına Göre Ortalama Finansal Performans Değeri” olan 6’ya bölünmesi ile elde edilmiştir.

Tablo 5. Sigorta Şirketlerinin Finansal Performans Endeksleri (2011-2014)

\begin{tabular}{|c|c|c|c|c|c|c|}
\hline Sigorta Şirketi & 2011 & 2012 & 2013 & 2014 & $\begin{array}{c}\text { Ortalama Görece } \\
\text { Finansal Performans } \\
\text { Endeksi (2011-2014) } \\
\text { (Sıra Puanına Göre)* }\end{array}$ & $\begin{array}{c}\text { Ortalama Görece Finansal } \\
\text { Performans Endeksi } \\
(2011-2014) \\
\text { (Yüzde Puana Göre) }^{* *}\end{array}$ \\
\hline AKGRT & 6 & 6 & 6 & 5 & 5,75 & 95,83 \\
\hline ANSGR & 4 & 2 & 4 & 6 & 4,00 & 66,67 \\
\hline GUSGR & 5 & 5 & 1 & 4 & 3,75 & 62,50 \\
\hline HALKS & 2 & 4 & 5 & 3 & 3,50 & 58,33 \\
\hline RAYSG & 3 & 3 & 3 & 2 & 2,75 & 45,83 \\
\hline AVIVA & 1 & 1 & 2 & 1 & 1,25 & 20,83 \\
\hline \multicolumn{5}{|c|}{ ORTALAMA GÖRELİ EŞIK DEĞER } & 3,50 & 58,33 \\
\hline
\end{tabular}

* Sıralama Değeri: En yüksek endeks değeri 6, En düşük endeks değeri l'dir.

** Yüzde Değeri: En yüksek\% değer 100, En düşük yüzde değer yaklaşık 16,67'dir. 
Tablo 5'te ortalama finansal performans endeksine göre görece performansı en yüksekten en düşüğe doğru firma sıralamasının "Ak Sigorta", "Anadolu Sigorta", "Güneş Sigorta", "Halk Sigorta", "Ray Sigorta" ve "Aviva Sigorta" şirketleri olduğu görülmektedir. Bu şirketlerden ilk üç sırada yer alanlarının Tablo 5 'te yer alan Ortalama Görece Eşik Değerlerin üzerinde puanlara sahip oldukları, dördüncü sırada yer alan şirketin bu değerlere eşit puanlara sahip olduğu, son iki sırada yer alan firmaların ise bu değerlerin altında puanlara sahip oldukları görülmüştür.

Ak Sigorta şirketinin ortalama görece sıra puanının 5,75 ile en yüksek puan olan 6'ya oldukça yakın olduğu dolayısıyla yüzde puanının da 95,83 ile en yüksek yüzde puan olan 100 'e oldukça yakın olduğu görülmektedir. Dolayısıyla Ak Sigorta şirketinin tüm yıllar için yüksek bir görece finansal performansı göstermiş olduğu yorumu yapılabilmektedir.

Anadolu Sigorta şirketinin 4,00 ortalama görece sıra puanı ile ikinci sırada yer aldığı, ancak 2012 yılında diğer yıllara göre oldukça düşük bir görece finansal performans sergilediği görülmektedir. Şirketin ortalama sıra puanının en yüksek değer olan 6'dan uzak olması nedeniyle yüzde puanının da 66,67 olarak hesaplandığ 1 görülmüştür. Bulgular, Anadolu Sigorta şirketinin ikinci sırada yer almakla birlikte, birinci s1rada yer alan şirkete göre görece finansal performansının düşük olduğunu göstermektedir.

Güneş Sigorta şirketinin 3,75 ortalama görece sıra puanı ile üçüncü sırada yer aldığı, daha yüksek bir s1rada yer alamamasının en önemli nedeninin ise 2013 yılında göstermiş olduğu görece düşük finansal performansı olduğu görülmektedir. Şirketin ortalama sira puanının en yüksek değer olan 6 'dan uzak olması nedeniyle yüzde puanının da 62,50 olarak hesaplandığ 1 görülmüştür. Bulgular, Güneş Sigorta şirketinin üçüncü sırada yer almakla birlikte, ikinci sırada yer alan şirkete oldukça yakın görece değerlere sahip olduğu, ancak birinci sırada yer alan şirkete göre görece finansal performansının düşük olduğunu göstermektedir.

Halk Sigorta şirketinin 3,50 ortalama görece sıra puanı ile dördüncü sırada yer aldığı, en yüksek görece finansal performansinı sirasiyla 2013 ve 2012 yillarında göstermiş olduğu görülmektedir. Bu şirketin de ortalama sıra puanının en yüksek değer olan 6 'dan uzak olması nedeniyle yüzde puanının da düşük bir değer olan 58,33 olarak hesaplandığı görülmüștür. Bu şirketin, Tablo 5'te yer alan Ortalama Görece Eşik Değerle eşit puanlara sahip olması nedeniyle, görece ortalama finansal performansa sahip şirket olduğu görülmektedir.

Ray Sigorta şirketinin 2,75 ortalama görece sıra puanı ve 45,83 yüzde puanı ile beşinci sırada yer aldığ 1 ve kendisinden önceki tüm şirketlerden oldukça uzak bir görece finansal performansa sahip olduğu görülmektedir. Ayrıca bu şirketin Ortalama Görece Eşik Değerlerin de altında görece ortalama finansal performansa sahip olduğu görülmektedir.

Aviva Sigorta şirketinin 1,25 ortalama görece sira puanı ve 20,83 yüzde puanı ile son sırada yer aldığ ve altı şirketi kapsayan sıralamada 2013 yılında ikinci sirada, 2011, 2012 ve 2014 yıllarinda ise son sirada yer aldığı görülmüştür. Ayrıca bu şirketin görece ortalama puanlarının, taban puanlara oldukça yakın değerlerde olduğu da gözlemlenmektedir.

\section{Sonuç}

Gelişen bir finans piyasasına sahip olan Türkiye'de, sigorta sektörünün de bu gelişmeye uyum sağladığı görülmektedir. Özellikle bireysel emeklilik sisteminin getirilmesi ve devlet destekli bir yapıya kavuşturulması ayrıca sigorta sektörü ile ilgili yasalara yönelik iyileştirmeler, bu sektörün gelişimine önemli katk1larda bulunmaktadır.

$\mathrm{Bu}$ çalışma kapsamında elde edilen bulgular az sayıda sigorta şirketinin halka açı olması nedeniyle sınırlı olmakla birlikte, altı şirketin birbirleriyle karşılaştırmalı finansal performans değerlendirmesini sunması açısından başta yatırımcılar ve bu şirketlerin yöneticileri açısından önem taşımaktadır. Ayrıca bu ampirik çalışma ile sektörün büyük firmalarının finansal performansı değerlendirilmiş olduğundan, çalışma sonuçlarının kısmen de olsa sektörün değerlendirilmesinde kullanılmasını sağlayabilmektedir.

Bu çerçevede, çalışmaya dahil edilen on adet mali oranın TOPSIS yöntemi ile yapılan finansal performans değerlendirmesi sonuçlarına göre; firmalardan Tablo 5'te gösterilen ilk dört firmanın ortalama değerlere göre farklı düzeylerde de olsa finansal açıdan başarılı olduğu, son iki firmanın ise başarısız olduğu değerlendirmesi yapılabilir. Dolayısıyla sonuçlar, sek- 
törde finansal açıdan başarılı firmaların varlığına işaret etmektedir. Burada altı çizilmesi gereken bir konu çalıșmanın sınırlarıyla ilgilidir. Çalıșma sonuçlarına ilișkin değerlendirmeler, ilgili dönem ve oranlarla yapılan analiz sonuçlarına yöneliktir. Dolayısıyla bu çalışma, her ne kadar 2011-2014 dönemini kapsıyor olsa da bir durum analizi niteliğindedir. Dolayısıyla yatırımcıların, şirket yöneticilerinin ve diğer ilgili kesimlerin sigorta şirketlerinin finansal performansına yönelik benzeri analizleri sıklıkla tekrarlamasına, bu analizleri farklı karar kriterleri ile uygulamasına ihtiyaç duymaları söz konusu olabilir.

$\mathrm{Bu}$ çalışma ve ilgili literatür, firmaların performans analizinde TOPSIS yönteminin uygulanabilirliğini ortaya koymakla birlikte farklı yöntemlerle de benzeri çalışmaların yapılması akademik ve uygulamaya dönük farklı yaklaşımların ortaya konulması açısından önem taşımaktadır.

\section{Kaynakça}

Akotey, J. O., Sackey, F. G., Amoah, L., Manso, R. F. (2013). Thefinancialperformance of life insurancecompanies in Ghana.The Journal of Risk Finance, 14 (3), 286-302.

Akyüz, Y., Bozdoğan T., Hantekin E. (2011). TOPSIS Yöntemiyle Finansal Performansın Değerlendirilmesi ve Bir Uygulama. Afyon Kocatepe Üniversitesi İktisadi ve İdari Bilimler Fakültesi Dergisi, 13 (1), 73-92.

Almajali, A. Y., Alamro, S. A., Al-Soub, Y. Z. (2012). Factors Affecting the Financial Performance of Jordanian Insurance Companies Listed at Amman Stock Exchange. Journal of Management Research, 4 (2), 266-289.

Aytekin, S., Sakarya, Ş. (2013). BIST'de İşlem Gören Gıda İşletmelerinin TOPSIS Yöntemi ile Finansal Performanslarının Değerlendirilmesi. Yönetim ve Ekonomi Araştırmaları Dergisi, 21, 30-47.

Başpınar, A. (2005). Finansal Analiz Tekniklerinin Sigorta Şirketi Mali Tablolarına Uygulanması. Maliye Dergisi, 149, 5-35.
Bawa,S.K.,Chattha, S. (2013). Financial Performance of Life Insurers in Indian Insurance Industry. Pacific Business Review International, 6(5), 44-52.

Curak, M.,Lončar, S.,Poposki, K. (2009). Insurance Sector Development and Economic Growth in Transition Countries. International Research Journal of Finance and Economics, 34, 29-41.

Çonkar, K.,Elitaş, C.,Atar, G. (2011). İMKB Kurumsal Yönetim Endeksinndeki (XKURY) Firmaların Finansal Performanslarının TOPSİS Yöntemi ile Ölçümü ve Kurumsal Yönetim Notu ile Analizi. İstanbul Üniversitesi İktisat Fakültesi Mecmuasl, 61(1), 81-115.

Demireli, E. (2010). TOPSİS Çok Kriterli Karar Verme Sistemi: Türkiye'deki Kamu Bankaları Üzerine Bir Uygulama. Girişimcilik ve Kalkınma Dergisi, 5(1), 101-112.

Dumanoğlu, S., Ergül, N. (2010). İMKB'de İşlem Gören Teknoloji Şirketlerinin Mali Performans Ölçümü. Muhasebe ve Finansman Dergisi, 48, 101-111.

Ege, İ., Topaloğlu, E. E.,Özyamanoğlu, M. (2013). Finansal Performans ile Kurumsal Yönetim Notları Arasındaki İlişki: BIST Üzerine Bir Uygulama. Akademik Araştırmalar ve Çalışmalar Dergisi, 5(9), 100-117.

Ergül, N. (2014). BİST-Turizm Sektöründeki Şirketlerin Finansal Performans Analizi.Çankırı Karatekin Üniversitesi İktisadi ve İdari Bilimler Fakültesi Dergisi, 4 (1), 325-340.

Genç, Ö. (2002). Sigortacilık Sektörü ve Türkiye’de Sigorta Sektörünün Fon Yaratma Kapasitesi. Türkiye Kalkınma Bankası A.Ş.

Hazine Müsteşarlı̆̆ı 2014 yılı Sigortacılık ve Bireysel Emeklilik Faaliyet Raporu. https:// www.hazine.gov.tr/tr-TR/Rapor-SunumSayfasi mid= $247 \&$ cid $=28 \& \mathrm{~nm}=43$, (Erişim Tarihi: 16.09.2015). 
Hwang, C-L., Yoon, K. (1981). MultipleAttributeDecisionMaking: Methodsand Applications. M. Beckmannand H.P. Künzi (Ed.). LectureNotes in Economicsand Mathematical Systems, Managing içinde. New York, Berlin Heidelberg: Springer-Verlag.

İç, Y. T., Tekin, M., Pamukoğlu, F. Z., Yıldırım, S. E. (2015). Kurumsal Firmalar için Bir Finansal Performans Karşılaştırma Modelinin Geliştirilmesi.Journal of the Faculty of Engineering and Architecture of Gazi University, 30 (1), 71-85.

Jahanshahloo, G. R., Hosseinzadeh Lotfi, F., Izadikhah, M. (2006). Extension of the TOPSIS method for decision-making problems with fuzzy data. Applied Mathematics and Computation, 181, 1544-1551.

Kahya, M. (2000). Sigorta Sektörünün Ekonomik Kalkınmadaki Yeri ve Önemi ile Fon Yaratma İşlevi ve Sermaye Piyasalarındaki Etkinliği. Reasürör, 37, 22-35.

Kamuyu Aydınlatma Platformu (KAP). Finansal Tablolar, https://www.kap.gov.tr/, (Erişim Tarihi: 02.07.2015).

Kasturi, R. (2006). Performance Management in Insurance Corporation. Journal of Business Administration Online, 5 (1), 1-16.
Kaya, E. Ö., Kaya, B. (2015). Türkiye’de Hayat Sigortası Şirketlerinin Finansal Performansını Belirleyen Firmaya Özgü Faktörler: Panel Veri Analizi. Finansal Araştırmalar ve Çalışmalar Dergisi, 7 (12), 93-111.

Kayaköy Taş, M. (2015). Dünya Sigorta Pazarında Türkiye’nin Yeri. İstanbul Ticaret Üniversitesi Sosyal Bilimler Dergisi, 14 (27), 133-148.

Ömürbek, V., Kınay, B. (2013). Havayolu Taşımacılığı Sektöründe TOPSIS Yöntemiyle Finansal Performans Değerlendirmesi. Süleyman Demirel Üniversitesi İktisadi ve İdari Bilimler Fakültesi Dergisi, 18(3),343-363.

Yayar, R., Baykara, H. V. (2012). TOPSIS Yöntemi ile Katılım Bankalarının Etkinliği ve Verimliliği Üzerine Bir Uygulama. Business and Economics Research Journal, 3 (4), 21-42.

Yllmaz Türkmen, S., Çağıl, G. (2012). İMKB’ye Kote Bilişim Sektörü Şirketlerinin Finansal Performanslarının TOPSIS Yöntemi ile Değerlendirilmesi. Maliye Finans Yazıları, 26 (95), 59-78. 